\title{
PRINCETON
}

THE ARA PACIS AUGUSTAE AND THE IMAGERY OF ABUNDANCE IN LATER GREEK AND EARLY ROMAN IMPERIAL ART David Castriota

125 halftones.

Cloth: $£ 39.50$ ISBN 0-691-03715-9

Due July 1995

WHOM GODS DESTROY

Elements of Greek and Tragic Madness

Ruth Padel

Cloth: £19.95 ISBN 0-691-03360-9

\section{IN AND OUT OF THE MIND}

Greek Images of the Tragic Self Ruth Padel

Paper: £10.95 ISBN 0-691-03766-3

THE COMING OF THE GREEKS

Indo-European Conquests in the Aegean and the Near East

Robert Drews

Paper: f 12.95 ISBN 0-691-02951-2

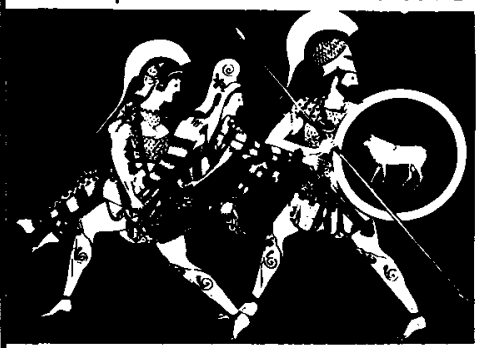

EMPIRE TO COMMONWEALTH

Consequences of Monotheism in Late Antiquity

Garth Fowden

Paper: f10.95 ISBN 0-691-01545-7

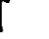

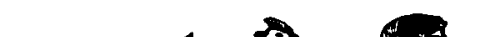

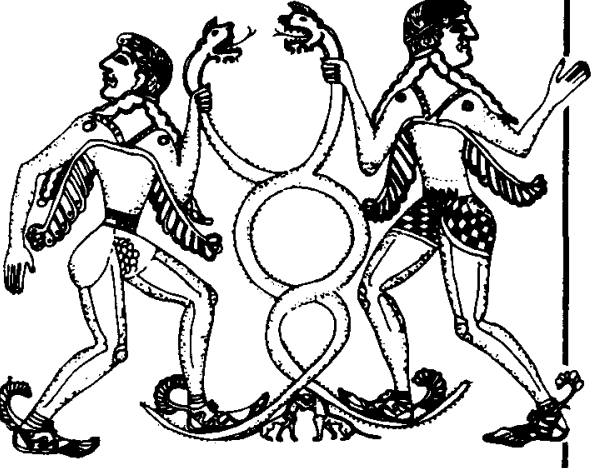

Winner of the Archaeological Institute of America's James R. Wiseman Book Award

\section{DAIDALOS AND THE ORIGINS OF} GREEK ART

\section{Sarah P. Morris}

63 halftones.

Paper: E24.95 ISBN 0-691-00160-X

\section{Expandededition}

With a new introduction, notes, and bibliography by John Carswell

\section{ARAB SEAFARING}

In the Indian Ocean in Ancient and Early Medieval Times

George F. Hourani

Paper: £10.95 ISBN 0-691-00032-8

Cloth: $\{27.50$ ISBN 0-691-00170-7

Due July 1995

\section{Princeton University Press}




\section{Simonides:}

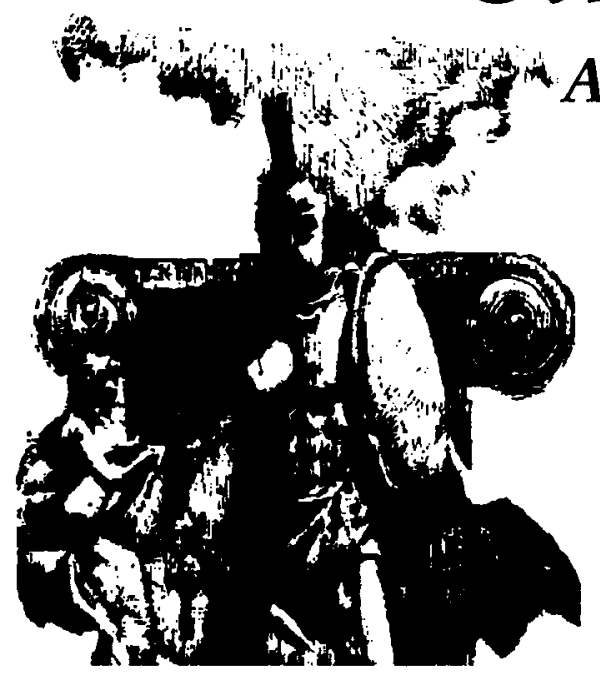

A Historical Study by J. H. Molyneux

"The largest and most important work written on Simonides."

\section{-D.L. Page}

Further Greek Epigrams

"Molyneux's work is a scholarly and exhaustive analysis that makes a significant contribution to ancient Greek literary history."

-Gordon Kirkwood

In his examination of the public life and poetic career of Simonides, Prof. $\mathrm{J}$. H. Molyneux has provided a thorough examination of all the documentary evidence available with respect to one of history's major choral lyric poets.

Simonides: A Historical Study offers a judicious assessment of the evidence for dating of events and poetry in the various stages of Simonides' career. In analyzing this information, Prof. Molyneux considers the occasion and date of the poems of Simonides; the dates of his association with various patrons; his whereabouts and movements at various stages of his poetic career; and his relationship with the communities, governments or individuals for whom he wrote. This meticulous study is certain to be of great value to both literary and historical scholars.

Senior Lecturer in the Classics at Nottingham University in England, Dr. Molyneux earned his doctorate from the University of Sheffield. His writings have appeared in numerous journals, and he has presented papers to many of the most prestigious scholarly organizations.

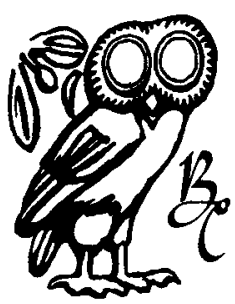

ISBN 0-86516-222-0 Hardbound, $\$ 39.00$

ISBN 0-86516-223-9 Paperbound, $\$ 24.00$

Order from:

Bolchazy-Carducci Publishers, Inc. 1000 Brown St., Unit 101

Wauconda, IL 60084

(708) 526-4344: Fax (708) 526-2867 


\section{Plato in the Italian Renaissance}

\section{By James Hankins}

Plato in the Italian Renaissance, the first book-length treatment of Renaissance Platonism in over fifty years, is a study of the dramatic revival of interest in the Platonic dialogues in Italy in the fifteenth century. Through a richly contextual study of the translations and commentaries on Plato, James Hankins seeks to show how the interpretation of Plato was molded by the expectations of fifteenth-century readers, by the need to protect Plato against his critics, and the broader hermeneutical assumptions and practices of the period.

The second half includes 20 appendices which treat of the dates, character, and sources of the translations and commentaries discussed in the first half. It also contains a catalogue raisoné of texts illustrative of Plato in the Quattrocento, comprising new critical editions of 59 texts, thirty-eight of them hitherto unpublished. The volume ends with a complete catalog of manuscripts and printed editions of Renaissance Latin translations of Plato, an incipitarium, and full indexes.

James Hankins received his A.B. in Classics at Duke University and his Ph.D. in History at Columbia University under Eugene F. Rice, Jr., where he also served for a number of years as assistant to Paul Oskar Kristeller. He has published and co-published The Humanism of Leonardo Bruni, Supplementum Festivum: Studies in Honor of Paul Oskar Kristeller and numerous articles.
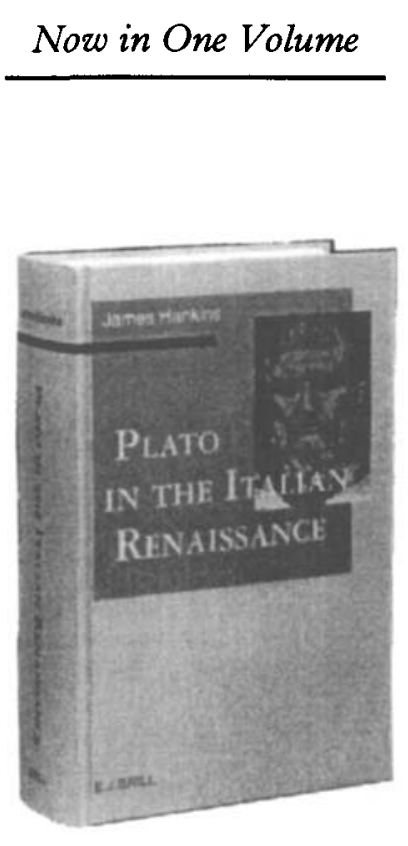

- Columbia Studies in the Classical Tradition, 17

- 3rd impression 1994. (xxxii, 849 pp.)

- ISBN 9004 I0095 4

- Bound

- NLG 250.00/US\$ I 43.00

All our titles can be found on Internet by gophering to ejbrill.infor.com: 4900

Prices and data are subject to change without prior notice and are exclusive of handling costs. All prices are exclusive of VAT in EC-countries. US\$ prices are valid for USA and Canada only. Offices in The Netherlands and Germany.

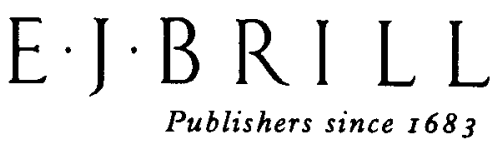




\section{Classical Literature}

\section{Wild Justice}

\section{A Study of Euripides' Hecuba JUDITH MOSSMAN}

This is the first book-length study of Hecuba in English, re-evaluating completely this important, yet often maligned Euripides play.

Oxford Classical Monographs

0-19-814789-9, 296 pp., 2 halftones, Clarendon Press $£ 35.00$

\section{Essays on Plutarch's Lives}

\section{Edited by BARBARA SCARDIGLI}

This volume brings together the work of a wide range of international scholars on the most important themes in Plutarch's Greek and Roman Lives.

0-19-814076-2, 410 pp., Clarendon Press £45.00

\section{NEW IN PAPERBACK}

\section{Aeschylus: The Seven Against Thebes}

Edited with an introduction and commentary by G. O. HUTCHINSON

'A good and thoroughly reliable edition.'

A.F. Garvie, Classical Review

'erudite and immensely thorough ... a valuable contribution to the study of the Septem'

Journal of Hellenic Studies

A major edition of Aeschylus' play, the Septem Contra Thebas or Seven Against Thebes, providing a significantly new text, introduction, and full scale commentary.

0-19-814999-9, 290 pp., Clarendon Paperbacks £12.95

\section{NEW IN PAPERBACK Aristophanes: Frogs}

Edited with introduction and commentary by Sir KENNETH DOVER

'original, incisive, detailed, sensible, witty ... the commentary is perceptive, undogmatic, wideranging, amusing, unpredictable and a pleasure to read. Particularly welcome are its exquisitely detailed discussion of meter, frequent reference to secondary literature, and generous translation of colloquialisms, particles, obscure vocabulary, lyric.' Bryn Mawr Classical Review

- An indispensable commentary on this celebrated Greek comedy

- Includes the complete Greek text, and a comprehensive introduction 0-19-815005-9, 414 pp., Clarendon Paperbacks £13.95

\section{NEW IN PAPERBACK Shakespeare and Ovid JONATHAN BATE}

'fascinating book ... wipes out the memory of static classroom excerpts and reveals Ovid in his full splendour'

Spectator

Examining the full range of Shakespeare's works, this is the first comprehensive account of the relationship between Shakespeare and his favourite poet, Ovid.

0-19-818324-0, 308 pp., Clarendon Paperbacks £12.95 


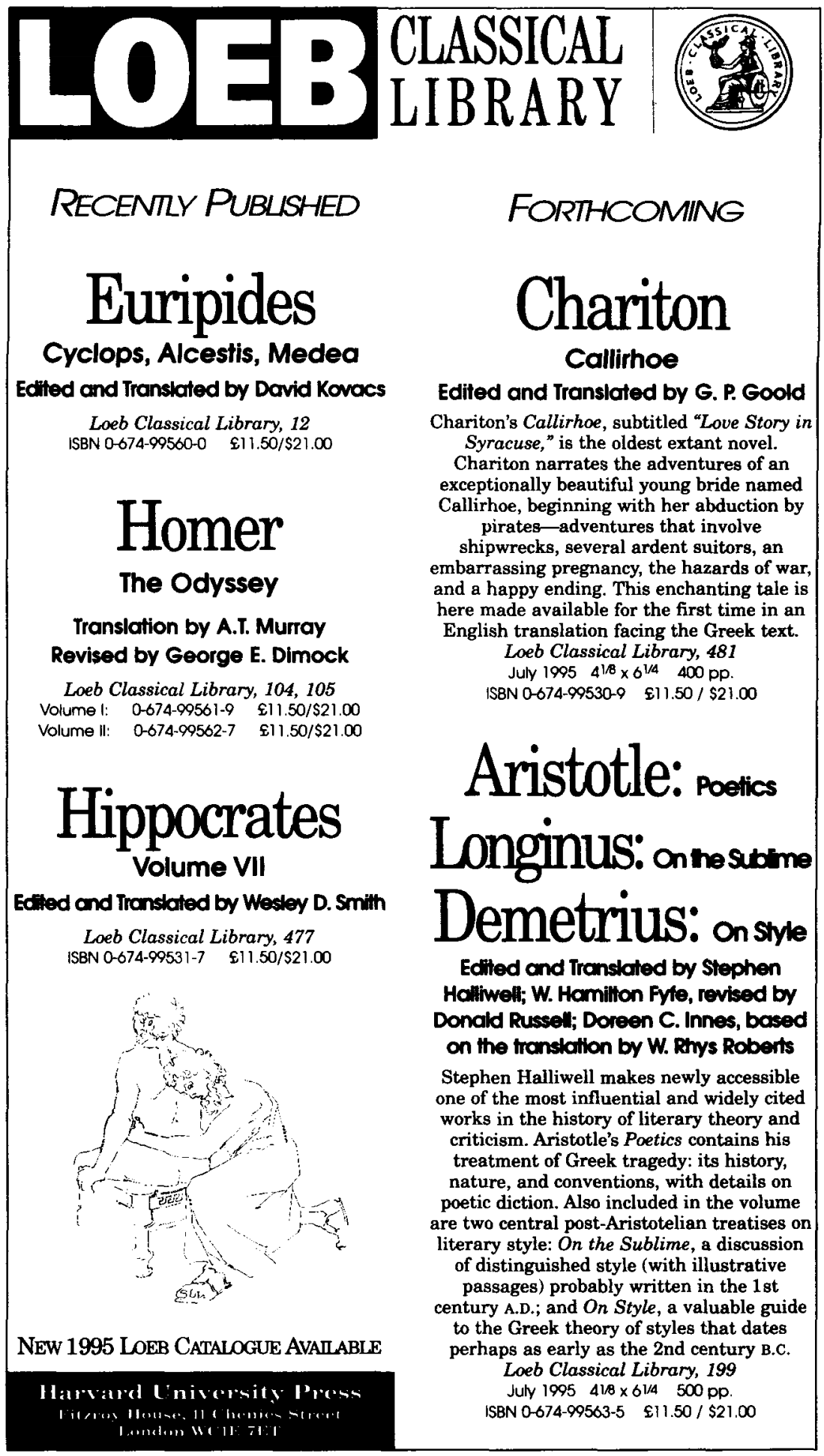




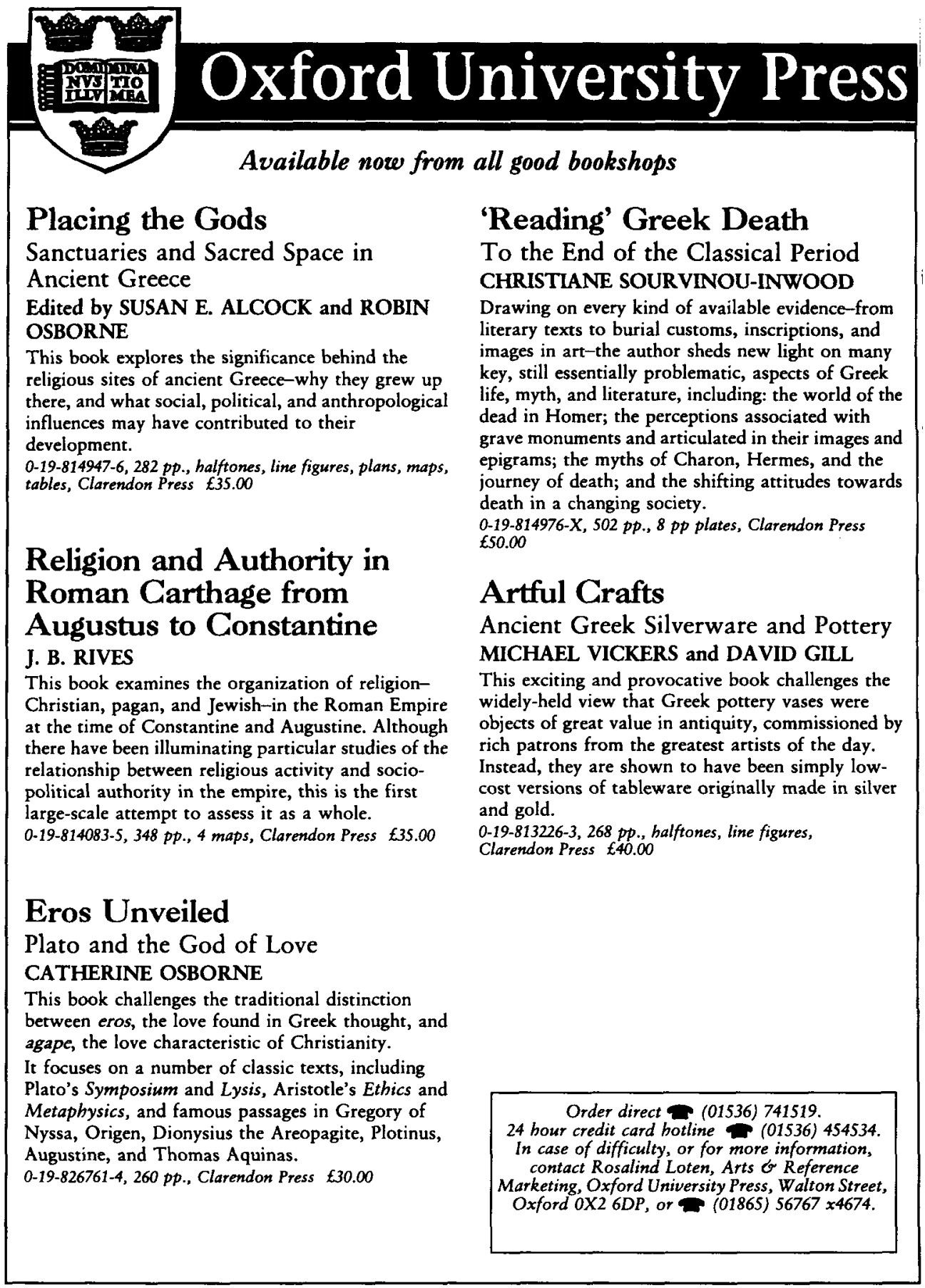




\section{CAMBRIDGE}

\section{Literacy and Power in the Ancient World}

Edited by ALAN K. BOWMAN and GREG WOOLF

Was writing a revolutionary innovation, prompting or participating in social change, or a fundamentally repressive and disciplinary technology? This book consists of a series of studies ranging over the whole of the Mediterranean world and much of northern Europe during a period of more than a millennium (c.600 BC-A D 800). f37.50 net HB $052143369 \times 256 \mathrm{pp}$.

\section{Sextus Empiricus: Outlines of Scepticism}

JULIA ANNAS and JONATHAN BARNES

Outlines of Scepticism is a work of major importance for the history of philosophy, being the fullest extant account of ancient Scepticism and also one of our most copious sources of information about the other Hellenistic philosophies. This is an accurate and readable translation with a short introduction, and brief annotation.

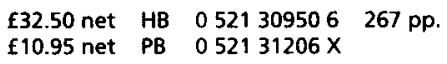

\section{Myth and Poetry in Lucretius}

\section{MONICA R. GALE}

Dr Gale considers De Rerum Natura against the background of earlier and contemporary views of myth, and suggests that Lucretius was well aware of the tension between his two roles as poet and philosopher, and attempted to resolve it by developing a bold and innovative theory of myth and poetry.

f35.00 net HB 0521451353274 pp.

Cambridge Classical Studies

\section{Papers in Hellenistic Philosophy}

\section{JACQUES BRUNSCHWIG}

Translated by JANET LLOYD

This collection makes available in English twelve papers by the distinguished French scholar, Jacques Brunschwig. The essays deal with problems arising in the texts and doctrines of the three major philosophical schools of the Hellenistic period Epicureanism, Stoicism and Scepticism.

f45.00 net HB $0521417120291 \mathrm{pp}$.

\section{Now in paperback}

\section{The Art of Vase-Painting in Classical Athens}

\section{MARTIN ROBERTSON}

Martin Robertson draws together the results of a life-time's study of Greek vasepainting, tracing the history of figure-drawing on Athenian pottery from the invention of the 'red-figure' technique in the later archaic period to the abandonment of figured vase-decoration two hundred years later.

f24.95 net PB $0521338816 \quad 362$ pp.

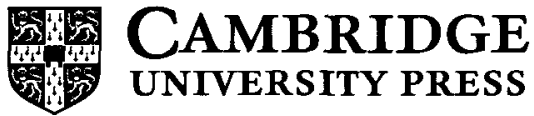

The Edinburgh Building, Cambridge CB2 2RU 
Celebrating 2500 years of democracy

\section{Ritual, Finance, Politics}

Athenian Democratic Accounts

Presented to David Lewis

Edited by ROBIN OSBORNE and SIMON HORNBLOWER

Two thousand five hundred years ago democracy was born in classical Athens. This collection of essays by twenty-two leading scholars from the UK, Europe, and America is a twin celebration-to mark both this occasion and the 65th birthday of the internationally renowned Professor of Ancient History at Oxford, David Lewis.

0-19-814992-1, 426 pp., frontispiece, balftone and line figures, Clarendon Press $£ 45.00$

\section{Theopompus of Chios}

History and Rhetoric in the Fourth Century BC

\section{MICHAEL ATTYAH FLOWER}

Theopompus of Chios was one of the most important ancient Greek historians of the fourth century BC. This new study explores his historical method and the intellectual milieu in which he lived. 0-19-814079-7, 264 pp., Clarendon Press £30.00

\section{NEW IN PAPERBACK}

\section{Goths and Romans 332-489}

\section{PETER HEATHER}

'compelling re-reading of Gothic and Roman history

\section{... a masterful account'}

\section{Historian}

Oxford Historical Monographs

0-19-820535-X, 394 pp., figures, maps, paperback, Clarendon Press 616.95

Available now from all good bookshops.

Order direct on (01536) 741519. 24 hour credit card botline 101536 ) 454534.

In case of difficulty, or for more information, contact Rosalind Loten, Arts $\sigma$ Reference Marketing, Oxford University Press, Walton Street, Oxford OX2 6DP, or (01865) $56767 \times 4674$. 


\section{W Walter de Gruyter Berlin • New York}

\section{Maximus Tyrius Philosophumena $-\Delta \mathrm{l} \alpha \lambda \varepsilon \xi \varepsilon l \varsigma$}

Edited by George Leonidas Koniaris

1995. Large-octavo. LXXXIII, 527 pages.

Cloth DM 390,-/öS 3042,-/sFr 370,- ISBN 3-11-012833-0

(Texte und Kommentare, Vol. 17)

Critical edition of the Lectures of Maximus of Tyre (Phoenicia), a rhetorician and eclectic philosopher of the 2 nd cent. A. D.

The $\Delta t \alpha \lambda \varepsilon \xi \varepsilon 1 \varsigma$ of Maximus of Tyre contribute to our knowledge of the Cynic diatribe, the Second Sophistic, and Middle Platonism. They also exemplify the intellectual syncretism of the time - in Maximus, for example, Asianism joins forces with Atticism, and philosophy diluted in rhetoric becomes manneristic belles-lettres.

The edition is based on a reevaluation of codex $R$ (Parisinus graecus 1962, late 9th cent.: codex unicus) and replaces the outdated edition of H. Hobein (1910).

Price is subject to change

Walter de Gruyter \& Co • Berlin - New York - Genthiner Straße 13 10785 Berlin - Telefon: (030) 260 05-0 • Telefax: (030) $26005-222$ 
Founded in 1886, The Classical Review publishes reviews of new work dealing with the literatures and civilisations of ancient Greece and Rome. Over three hundred books are reviewed each year, the full length reviews being followed by notices of less important works. The journal can be regarded as a companion to The Classical Quarterly.

VOLUME 45 (TWO ISSUES) $\$ 39 /$ US\$70

Founded in 1906, The Classical

Quarterly is one of the major journals devoted to Greco-Roman antiquity in the English-speaking world. It publishes research papers and short notes in the fields of language, literature, philosophy and history. The Classical Quarterly appears in May and December each year.

VOLUME 45 (TWO ISSUES) $\$ 39 /$ US\$70

Designed to meet the needs of a wide audience, and with an emphasis on the literary evaluation of the major Greek and Roman authors, Greece \& Rome publishes articles on ancient history, art, archaeology, religion, philosophy, and the classical tradition. Over 90 books are reviewed in each issue, and the annual supplements to the journal, New Surveys in the Classics, form a collection of surveys of particular authors, periods, or topics; the 1994 title was Greek Religion.

\section{VOLUME 42 (TWO ISSUES) $£ 32 /$ US $\$ 61$}

\section{ORDER FOKM}

Please enter my subscription to

\section{CLASSICAL REVIEW $\square$ CLASSICAL QUARTERLY : $\square$ GREECE \& ROMM}

Please send me a free sample copy of .

I enclose the correct remittance Please note: $\delta$ sterling rates apply in UK and Europe, USS rates elsewhere, and that customers in the EC and in Canada are subject to their local sales tax. Name. Address.

City/County.

Postcode.

Please debit my Diners / Mastercard / Visa / American Express Card

Number:

For further subscriptions information please write to:

Journals Marketing (F95), Oxford University Press,

Walton Street,Oxford OX2 6DP, U. K Fax: $(+44)(0) 1865267773$

PUBLISHED FOR THE CLASSICAL ASSOCIATION 


\section{CAMBRIDGE}

\section{Conquest and Empire}

The Reign of Alexander the Great

\section{A. B. BOSWORTH}

This acclaimed historical survey of the reign of Alexander the Great draws on ancient sources to present a new account of this fascinating and turbulent period.

'This is the book on Alexander we have all been waiting for.'

The Times Higher Education Supplement

f7.95 net $052140679 \times 352 \mathrm{pp}$.

\section{Politics in the Ancient World}

\section{I. FINLEY}

'... a splendid succession of illuminating insights ... provocative and entertaining ... written with all Sir Moses' characteristic clarity and panache.'

History of Political Thought

'... a brilliant analysis of the politics of the Greek and Roman city state ... a beautiful comparative study ... This is an important book.'

American Historical Review

f5.95 net $0521406730 \quad 160 \mathrm{pp}$.

\section{The Decipherment of Linear B}

\section{JOHN CHADWICK}

'In this present short books - lucid, concise and admirable - Chadwick tells us something of Ventris and his mind, and of the problems involved in the decipherment of Minoan-Mycenaean scripts. It is written for the layman and very well written. It is not only an account of a startling piece of philological and archaeological research, but a simple, moving human story.' The Spectator f6.95 net $0521398304 \quad 173 \mathrm{pp}$.

\section{J. G. Frazer: His Life and Work ROBERT ACKERMAN}

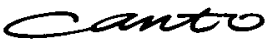

'.. an intellectual history of the age, as elegant as it is comprehensive'.

The Times

'Ackerman triumphantly succeeds in recreating the mental atmosphere of the late-Victorian world, suspended between religion and science.'

The Sunday Telegraph

f7.95 net $0521398258 \quad 358$ pp.

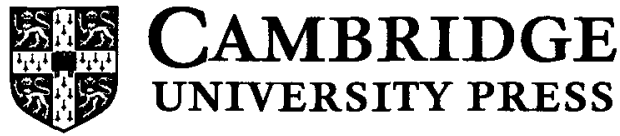

The Edinburgh Building, Cambridge CB2 2RU 
Renaissance Studies is a multi disciplinary journal which publishes articles and editions of documents on all aspects of Renaissance history and culture. The articles range over the art, architecture, history, religion, literature and languages of Europe during the period. The editions of important documents appear in their original languages, with an introduction, textual apparatus, notes and (occasionally) translations of the documents and sources into English The journal also contains a substantial book reviews section, as well as illustrated reviews of major exhibitions.

FORTHCOMING SPECIAL ISSUES INCLUDE,

Engtlsh and French Drama (March 1995)

Early Printed Books (September 1995)

Conformity and Dissent in Renaissance

Venice (March 1996)

RECENT \& FORTHCOMMG ARTICLES INCLUDE:

GILLIAN E. BRENNAN on foreigners in Elizabethan literature

JUDITH BRYCE on the Florentine

Academy

WILLIAM CAFERRO on the silk industry in Renaissance Florence

LUCIANO CHELES on the Studiolo of Urbino

CECIL H. CLOUGH Federico da

Montefeltro and the kings of Naples

STEPHEN CLUCAS on William Percy, ninth Earl of Northumberland

$P A U L$ GWYNNE on Nagonius

$S Y B I L J A C K$ on the English Revels accounts

ROBERT KNECHT on Blaise de Monluc

PAUL MURGATROYD on Johannes

Secundus

MICHAEL WOLFE on Henri III

WERNER WUNDERLICH on a newly indentified author, Johann II

\section{Renaissance Studies}

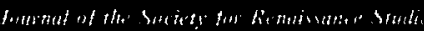

\section{ORDER FORM}

$\square$ Please enter my subscription to RENAISSANCE STUDIES Volume 9 (four issues):

$\square$ Institutions $£ 62$ / US\$1 12

Individual rates for members of:

$\square$ Society for Renaissance Studies $£ 29$ / US\$54

$\square$ Renaissance Society of America $£ 29$ / US\$54

$\square$ American Historical Association $£ 31$ / US\$56

Please note: $£$ sterling rates apply in UK and Europe USS rates elsewhere. Customers in the EC and in Canada are subject to their local sales tax.

$\square$ I enclose the correct remittance

$\square$ Please send me a sample copy

Name

Address

City/County

Postcode.

$\square$ Please debit my Mastercard/Visa/ Diners/American Express/Card no:

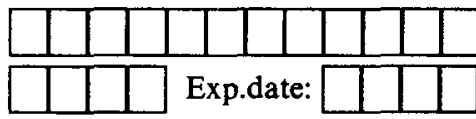

For further subscription information please contact: QIiv Journals Marketing (F95) Oxford University Press Walton Street, Oxford OX2 6DP, UK

Fax: $+44(0) 1865267773$ 
The Experiences of Tiresias explores how the Greek male defines himself in relationship to the feminine.

"In her generous and passionate manner, Nicole Loraux brings into bloom an entire field of Greek studies. ..."

-Catherine David, Le Nouvel Observateur Cloth: f29.95 ISBN 0-691-02985-7

\section{CALLIMACHUS AND HIS CRITICS}

\section{Alan Cameron}

Callimachus has usually been seen as the archetypal ivory-tower poet. Abundant evidence, much of it assembled here for the first time, suggests a very different story: a world of civic festivals rather than books and libraries, a world in which poetry and poets played a central and public role. In the course of his work, Alan Cameron casts fresh light on the lives, dates, works, and interrelationships of most of the other leading poets of the age.

Cloth: f37.50 ISBN 0-691-04367-1

\section{PANDORA \\ Women in Classical Greece \\ Edited by Ellen D. Reeder}

Spotlighting superb examples of classical Greek art together with recent findings in anthropology, social history, psychology, classics, and classical archaeology. Pandora offers a multi-faceted look at women in myth, ritual, and daily life in classical Greece.

400 illustrations, including 140 in color

Paper: f30.00 ISBN 0-691-01124-9 Cloth: f70.00 ISBN 0-691-01125-7

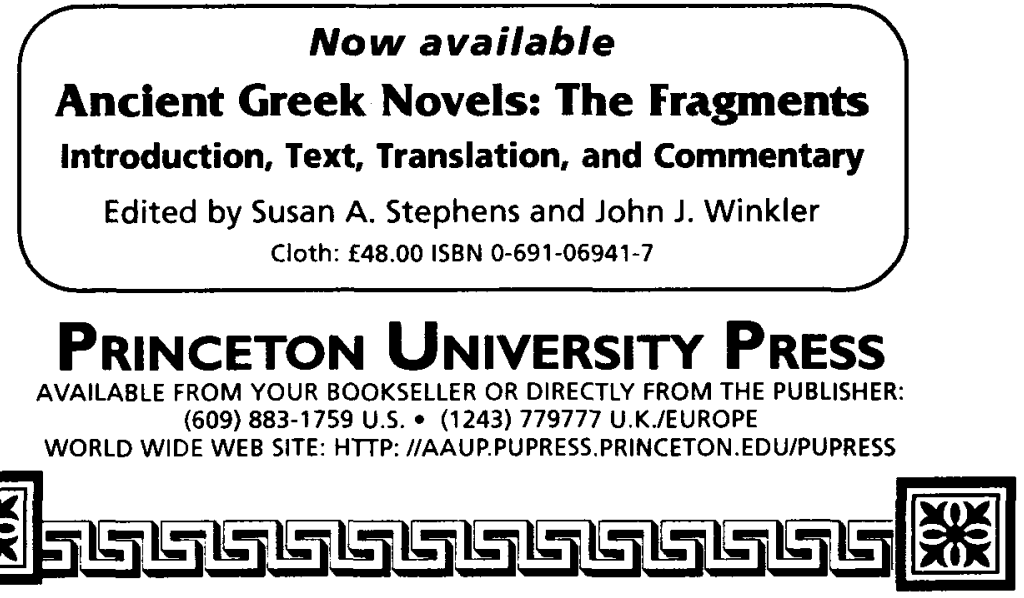




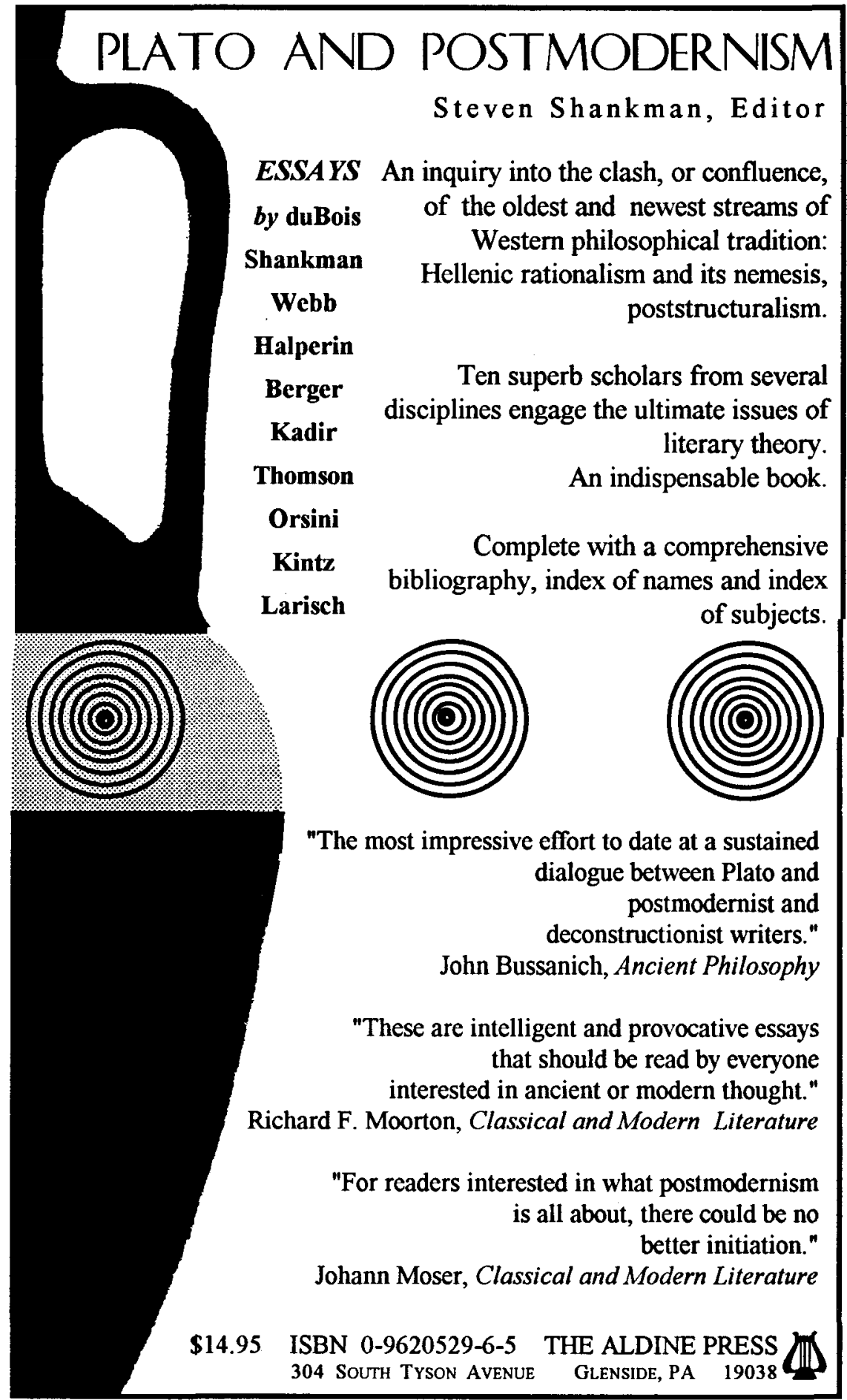




\section{NOTES TO CONTRIBUTORS}

1. One copy of an article will suffice. It will usually be returned if the contributor so requests on submitting it, but as the editors may wish to annotate it and furthermore cannot take responsibility for any loss, contributors should retain another copy.

2. Articles should be typed in double spacing on A4 paper and on one side of the paper only. Footnotes should be numbered consecutively and typed on separate sheets. Greek quotations need not be typed, but every letter must be clear and legible; especial care should be taken over accents and breathings.

3. Quotations in English, Latin, French, etc., should be put in single inverted commas, e.g.

...the phrase 'dux femina facti' has...

A quotation within a quoted passage has double inverted commas. Single words or self-contained phrases (such as fait accompli) may be underlined to indicate italics. Material inserted within a quotation is placed in square brackets:

'[The translator]... must ever be casting his eyes upwards from the copy to the original.'

4. References should normally be given in the footnotes, in the following form:

\section{BOOKS}

R. Syme, The Roman Revolution (Oxford, 1939), pp. 78-9

or op. cit., pp. 78-9.

E. Norden, Die antike Kunstprosa ${ }^{5}$ i.164-81

or op. cit. i.164-81.

F. Jacoby, FGrHist $328 \mathrm{~F} 4$.

Authors' initials should be stated, at least at their first mention. Abbreviations should not be assigned to books unless they are generally familiar (e.g. $O C D^{2}$ omitting full points).

\section{ARTICLES}

R. P. Winnington-Ingram. 'The Danaid Triology', JHS 81 (1961), 141-52

or R. P. Winnington-Ingram, JHS 81 (1961), 141-52.

Both year and volume number should be given.

Abbreviations may follow the style of Marouzeau's L'Année philologique.

\section{ANCIENT AUTHORITIES}

Aristophanes, Birds 135; Homer, Od. 1.1 (not a 1); Cic. Phil. 2.20 (not 2.8 or 2.8.20); Plin. N.H. 9.176 (not 9.83.176 or 9.83); Quint. 10.1.46; Soph. O.C. 225 (retain full points; do not use 1. or 1l., but, where necessary, line or lines).

B.C. should appear after, A.D. before, the number of the year. The following should not be italicized: op. cit., loc. cit., cf., ibid., s.v. 


\section{The Classical Association}

The main aims of the Classical Association are to promote and sustain interest in classical studies, to maintain their rightful position in universities and schools, and to give scholars and teachers opportunities of meeting and discussing their problems. It organizes an annual conference, lasting four or five days, in a university centre, and sponsors twenty-nine branches, most of which hold Greek and Latin Reading Competitions for Scholars. Its activities are fully reported in the annual Proceedings, issued free to all members.

The present membership of the Association is approximately 4,400. Membership is open to both individuals and to institutions at an annual subscription of $£ 3.00$ (life composition for individual members, $£ 63.00$ ). Members may obtain Classical Review, Classical Quarterly, and Greece \& Rome at greatly reduced prices. Application for membership and subscriptions for the journals should be addressed to the Hon. Treasurer, Richard Wallace, Department of Classics, University of Keele, Keele, Staffs. ST5 5BG. 